\section{Australian Journal of \\ Crop Science}

AJCS

ISSN:1835-2707

doi: 10.21475/ajcs.18.12.05.PNE647

\title{
Effects of legume green manure on the physicochemical quality of maize grains (Zea mays L.)
}

\author{
Georgiana E. de C Marques ${ }^{1}$, Kiany S. B. Cavalcante ${ }^{2}$, Lanna K. Silva ${ }^{3}$, Natilene M. Brito ${ }^{4}$, Jose F. S. Lima ${ }^{5}$ \\ and Emanoel G. de Moura ${ }^{6}$
}

${ }^{1}$ Major in Biotechnology and Biodiversity Network of Amazon, Federal University of Maranhão, 65080-805, São Luís, Maranhão, Brazil

${ }^{2}$ Major in Organic Chemistry, Federal Institute of Education, Science and Technology of Maranhão, 65030-005, São

Luís, Maranhão, Brazil

${ }^{3}$ Federal Institute of Education, Science and Technology of Maranhão, 65030-005, São Luís, Maranhão, Brazil

${ }^{4}$ Major in Analytical Chemistry, Federal Institute of Education, Science and Technology of Maranhão, 65030-005, São Luís, Maranhão, Brazil

${ }^{5}$ Federal Institute of Education, Science and Technology of Maranhão, 65030-005, São Luís, Maranhão, Brazil

${ }^{6}$ Major in Agronomy, Maranhão State University, 65054-970, São Luís, Maranhão, Brazil

\section{*Corresponding author: geurides@ifma.edu.br}

Abstract

The aim of this study was to assess the effects of low/high quality legume residue addition on the chemical composition and quality of maize grain. The experiment followed a randomized block design with a $6 \times 2$ factorial arrangement, and four repetitions. The plots comprised different combinations of leguminous plants (LC, LA, LG, GC, and GA) and one control group, whereas the subplots were simultaneously cultivated with QPM BR 473 and hybrid AG 7088 maize cultivars. Lipid, protein, starch, fiber, mineral residue, mineral, sugar, carbohydrate, and amino acid levels were analyzed. Legume-biomass treatments applied to the two cultivars affected all mineral contents in the grains, except for calcium. In hybrid cultivar, the legume-biomass treatment provided increased mineral, reducing sugar, and fiber contents. The LG, GA, and GC treatments showed higher protein content during cultivation than the control in both cultivars. In the QPM cultivar, throughout the two cultivations, each one of the legume-based treatments the highest contents for amino acids when compared to the control. The different effects of legume residue-based treatments on different cultivars are associated with efficient nitrogen deposition in the soil and with nitrogen accumulation in plants. Each of the chemical parameters analyzed in the maize cultivars displayed different levels when subjected to treatments using legumebiomass. Legume-biomass helped improve the physicochemical profile of maize grains in the assessed cultivars, including QPM.

Keywords: leguminous plants; chemical composition, grain quality, maize, sustainable.

Abbreviation: LC - Leucaena leucocephala Lam. and Clitoria fairchildiana Howard, LG - Leucaena leucocephala Lam. and Gliricidia sepium Jacq., LA - Leucaena leucocephala Lam and Acacia mangium Willd, GC - Gliricidia sepium Jacq. and Clitoria fairchildiana Howard, GA - Gliricidia sepium Jacq. and Acacia mangium Willd, QPM - quality protein maize.

\section{Introduction}

Maize (Zea mays L.) is an important energy source owing to its high digestible starch content. This cereal accounts for approximately $15 \%$ to $56 \%$ of the total calories consumed by people living in $25 \%$ of Latin American cities (Watson and Ramsted, 1999). Maize grain structure differs depending on its chemical composition, which shows a single fraction formed by the germ and the pericarp. Such a chemical profile makes maize grains part of the formulation adopted for food containing high good-quality lipid and protein levels (Prasanna et al., 2001; Brito et al., 2005; Naves et al., 2011) Starch represents approximately $70 \%$ of grain and germ mass in the endosperm, whereas proteins are responsible for approximately $30 \%$ of total grain mass (Prasanna et al., 2001). However, common maize species are a source of lowquality proteins because they hold high amounts of proteins belonging to the prolamin group, and minimal lysine and tryptophan levels (Young and Pellett, 1994; Vasal, 2001; Wegarya et al., 2011). These nutritional values are low for monogastric animals such as humans (Prasanna et al., 2001;

Vivek et al, 2008); therefore, mutant genes have been used to produce high-quality proteins through biofortification processes focused on developing quality protein maize (QPM) (Glória et al., 2004). In addition, food chemical composition naturally changes because of environmental and genetic factors (Mercadante et al., 1997). Changes in the chemical and physical quality of maize grains often result from management conditions in plant (Vyn and Tollenaar, 1998). Just as Vasconcellos (1994), nitrogen fertilization affects the quality of the grain. Nitrogen is the most important element affecting grain yield increase because it plays an important role in plant metabolism. Nitrogen is an 
important component of proetins, coenzymes, nucleic acids, cytochromes and chlorophyll molecules (Imolesi et al., 2001). Thus, plant response to nitrogen-based nutrition during the plant growth and development period presents a very complex nature, which is controlled by many genes expressed in a time-dependent system (Canas et al., 2011).Nitrogen addition to soil is typically done through chemical fertilizer applications, which can lead to groundwater contamination, soil acidification, gas emissions, and eutrophication (Pretty, 2008; Zhao et al., 2015). In addition, much of the nitrogen added to the soil is lost owing to surface runoff, nitrate leaching, ammonia volatilization, or bacterial competition (Garnett et al., 2009). Thus, it is worth improving nitrogen-use efficiency (NUE) to reduce the adverse effects of nitrogen fertilization. Therefore, green fertilization is an essential practice, because it uses legume residues as the nitrogen source for crops. Legume residues used in association with different fast/slow-decomposition residue combinations for soil coating may maximize covering through the adoption of different temporal cropdevelopment patterns and increased atmospheric nitrogen fixation (Luscher et al., 2016). Several studies have reported the effects of nitrogen application on maize grain yield; however, there is little evidence of nitrogen affecting the quality and quantity of chemical components in grains from different cultivars, including QPM (Wegarya et al., 2011).

The hypothesis addressed in the current study advocates that high/low-quality legume residue combinations affect the chemical composition of maize grains from different cultivars grown in cohesive soils. The aim of the present study was to assess the effects of high/low-quality legume residues on the chemical composition of maize grains in different cultivars.

\section{Results}

\section{Physicochemical analyses applied to maize grains from different cultivars}

Legume-biomass treatments showed significant effects on the minerals in the two cultivars $(p<0.05)$, except for calcium. The LC treatment, applied to the QPM cultivar in 2014, increased Mg, P, K, and Zn content in this cultivar, whereas the GA treatment increased the Fe content. All legume-based treatments increased the mineral contents in the hybrid cultivar, except for the Ca content. Maize cultivars did not show changes in mineral contents due to legume-biomass application in 2015 , except for the hybrid cultivar, which presented increased Mg content under the LC treatment. All other legume-based treatments increased the Fe content in this cultivar (Table 1).The effect of legumebiomass application on lipid, protein, mineral residue, sugar, fiber, starch, and carbohydrate contents showed significant differences $(p<0.05)$ in the two cultivars, in both cultivation years (Table 3 ). The LG treatment increased mineral residue and starch levels in the QPM cultivar in 2014, when compared to the control treatment. All legume-based treatments affected the sugar content in the QPM cultivar. The hybrid cultivar presented increased mineral content, as well as reduced sugar and fiber contents when it was subjected to the legume-biomass treatment. The starch content in the LC treatment was higher than that in the other treatments. The legume-biomass treatments applied to the QPM cultivar in 2015 only affected the carbohydrate content, but reduced the sugar and fiber contents in this cultivar. However, the legume-biomass treatment applied to the hybrid cultivar only enhanced the mineral content, but reduced the sugar and fiber contents in this cultivar.

The protein content in 2014 was significantly different $(p<$ 0.05 ) in the two cultivars (Fig. 2). However, protein content under the LG, GA, and GC treatments was higher than that recorded for the control treatment in both cultivars. All legume-biomass treatments applied to the hybrid cultivar in 2015 showed better results than the control, except for the LG treatment.

\section{Amino acids contents in maize cultivars}

The chromatographic method used to set the amino acid content was optimized according to variations in the mobile phase concentrations (Fig. 3 and Fig. 4). The chromatogram accurately separated the studied analytes without overlapping their peaks; however, it demanded prolonged analysis time, approximately $45 \mathrm{~min}$. Therefore, it was not possible to include the chromatograhic data for amino acid content for some treatments. The linearity interval set according to the analytical curves (Table 3 ), which resulted from five distinct concentration points, generated the regression equations, as well as their respective determination coefficients, $R^{2}$. These equations were based on Ordinary Least Squares. The differential effect of legumebiomass treatments on amino acid content in the two cultivars $(p<0.05)$ affected the quality of proteins found in the maize grains (Table 4). in the QPM cultivar, in both cultivation years, each a legume-based treatment has exceeded the contents of all analyzed amino acids when compared with the control. It is worth emphasizing that the LG treatment increased the aspartic acid, serine, arginine, and tryptophan contents in the 2015 crop. In addition, the GA treatment increased aspartic acid, serine, and glutamine contents in the hybrid cultivar in 2014. Moreover, the GC treatment increased aspartic acid, serine, glutamine, tryptophan, and arginine contents in the hybrid cultivar in 2015.

\section{Discussion}

Variations in the chemical parameters and grain quality in the assessed cultivars were analyzed with respect to the improved NUE derived from legume-biomass application. According to Franco and Balieiro (2000), the behavior of each legume species changes depending on local edaphoclimatic conditions. In addition, legumes tend to immobilize nutrients, mainly nitrogen, because legume cellulose and polyphenol content influences nitrogen mineralization in the short term (Cattanio et al., 2008). Maize genotypes show different nitrogen accumulation skills, which interferes with NUE, resulting in higher nitrogen uptake and absorption by plants (Worku et al., 2008). Higher tryptophan and protein concentrations are recorded when the nitrogen in the soil is better absorbed by plants (CIMMYT, 2004), a fact that corroborates results described in the present study. The different mineral contents recorded for the assessed cultivars arose from genetic and environmental factors, as well as the interaction between such factors. This interaction depends on the availability of 
Table 1. The $\mathrm{Ca}, \mathrm{Mg}, \mathrm{K}, \mathrm{P}, \mathrm{Fe}$, and $\mathrm{Zn}$ contents in maize grains from cultivars QPM and Hybrid, according to different treatments, in 2014 and 2015.

\begin{tabular}{|c|c|c|c|c|c|c|c|c|c|c|c|c|}
\hline \multirow[t]{2}{*}{ Treatments } & \multicolumn{2}{|c|}{$\begin{array}{l}\mathrm{Ca} \\
\left(\mathrm{g} \cdot \mathrm{kg}^{-1}\right)\end{array}$} & \multicolumn{2}{|c|}{$\begin{array}{l}\mathrm{Mg} \\
\left(\mathrm{g} \cdot \mathrm{kg}^{-1}\right) \\
\end{array}$} & \multicolumn{2}{|c|}{$\begin{array}{l}P \\
\left(\mathrm{~g} \cdot \mathrm{kg}^{-1}\right) \\
\end{array}$} & \multicolumn{2}{|l|}{$\begin{array}{l}\mathrm{K} \\
\left(\mathrm{g} \cdot \mathrm{kg}^{-1}\right) \\
\end{array}$} & \multirow{2}{*}{$\begin{array}{l}\begin{array}{l}\mathrm{Fe} \\
\left(\mathrm{g} \cdot \mathrm{kg}^{-1}\right)\end{array} \\
\text { QPM }\end{array}$} & \multicolumn{3}{|c|}{$\begin{array}{l}\mathrm{Zn} \\
\left(\mathrm{g} \cdot \mathrm{kg}^{-1}\right)\end{array}$} \\
\hline & & Hybrid & QPM & Hybrid & QPM & Hybrid & QPM & Hybrid & & Hybrid & QPM & Hybrid \\
\hline \multicolumn{13}{|l|}{2014} \\
\hline LC & $0.29 a$ & $0.32 \mathrm{a}$ & $1.03 \mathrm{a}$ & $1.06 \mathrm{a}$ & $3.24 \mathrm{a}$ & $3.42 \mathrm{a}$ & $1.88 \mathrm{a}$ & $1.84 \mathrm{a}$ & $0.4 \mathrm{~b}$ & $0.33 \mathrm{ab}$ & $0.082 a$ & $0.085 a$ \\
\hline LA & $0.34 a$ & $0.29 \mathrm{a}$ & $0.83 \mathrm{ab}$ & $0.84 a b$ & $2.5 \mathrm{ab}$ & $2.81 \mathrm{ab}$ & $1.49 a b$ & $1.54 \mathrm{ab}$ & $0.28 \mathrm{~b}$ & $0.3 \mathrm{ab}$ & $0.077 a$ & $0.072 b$ \\
\hline LG & $0.27 a$ & $0.28 a$ & $0.63 \mathrm{~b}$ & $0.68 \mathrm{~b}$ & $1.82 \mathrm{~b}$ & $2.51 \mathrm{ab}$ & $1.22 \mathrm{~b}$ & $1.39 \mathrm{~b}$ & $0.31 \mathrm{~b}$ & $0.53 a$ & $0.07 a$ & $0.07 \mathrm{~b}$ \\
\hline GA & $0.32 \mathrm{a}$ & $0.31 \mathrm{a}$ & $0.84 \mathrm{ab}$ & $0.76 \mathrm{~b}$ & $2.13 \mathrm{ab}$ & $2.52 \mathrm{ab}$ & $1.53 \mathrm{ab}$ & $1.45 \mathrm{ab}$ & $0.78 a$ & $0.39 \mathrm{ab}$ & $0.072 a$ & $0.072 b$ \\
\hline $\mathrm{GC}$ & $0.35 a$ & $0.31 \mathrm{a}$ & $0.84 \mathrm{ab}$ & $0.68 \mathrm{~b}$ & $2.75 \mathrm{ab}$ & $2.28 a b$ & $1.5 \mathrm{ab}$ & $1.39 \mathrm{~b}$ & $0.31 \mathrm{~b}$ & $0.3 \mathrm{ab}$ & $0.08 a$ & $0.075 a b$ \\
\hline C & $0.27 \mathrm{a}$ & $0.3 \mathrm{a}$ & $0.81 \mathrm{ab}$ & $0.62 \mathrm{~b}$ & $2.53 \mathrm{ab}$ & $2.2 \mathrm{~b}$ & $1.47 \mathrm{ab}$ & $1.42 \mathrm{~b}$ & $0.41 \mathrm{~b}$ & $0.27 b$ & $0.072 \mathrm{a}$ & $0.072 b$ \\
\hline \multicolumn{13}{|l|}{2015} \\
\hline LC & $0.29 a$ & $0.27 a$ & $1.09 \mathrm{a}$ & $1.06 \mathrm{a}$ & $3.61 \mathrm{a}$ & $3.26 \mathrm{a}$ & $1.88 \mathrm{a}$ & $1.84 \mathrm{a}$ & $0.15 \mathrm{a}$ & $0.14 \mathrm{a}$ & $0.08 a$ & $0.06 \mathrm{a}$ \\
\hline LA & $0.24 a$ & $0.25 \mathrm{a}$ & $0.9 a$ & $0.84 a b$ & $3.19 \mathrm{a}$ & $3.24 \mathrm{a}$ & $1.69 \mathrm{a}$ & $1.78 \mathrm{a}$ & $0.13 a$ & $0.12 \mathrm{a}$ & $0.06 a b$ & $0.06 a$ \\
\hline LG & $0.26 a$ & $0.29 \mathrm{a}$ & $1.12 \mathrm{a}$ & $0.68 \mathrm{~b}$ & $3.75 \mathrm{a}$ & $3.12 \mathrm{a}$ & $1.92 \mathrm{a}$ & $1.78 \mathrm{a}$ & $0.15 a$ & $0.13 a$ & $0.04 \mathrm{~b}$ & $0.07 \mathrm{a}$ \\
\hline GA & $0.25 a$ & $0.26 \mathrm{a}$ & $1.05 \mathrm{a}$ & $0.76 \mathrm{~b}$ & $3.63 \mathrm{a}$ & $3.15 \mathrm{a}$ & $1.82 \mathrm{a}$ & $1.79 \mathrm{a}$ & $0.13 \mathrm{a}$ & $0.13 a$ & $0.07 a b$ & $0.07 a$ \\
\hline $\mathrm{GC}$ & $0.26 a$ & $0.31 \mathrm{a}$ & $1.02 \mathrm{a}$ & $0.68 \mathrm{~b}$ & $3.25 \mathrm{a}$ & $3.02 \mathrm{a}$ & $1.78 \mathrm{a}$ & $1.82 \mathrm{a}$ & $0.14 a$ & $0.11 \mathrm{ab}$ & $0.08 \mathrm{a}$ & $0.07 a$ \\
\hline C & $0.28 a$ & $0.28 a$ & $0.93 \mathrm{a}$ & $0.62 b$ & $3.35 \mathrm{a}$ & $2.69 \mathrm{a}$ & $1.74 \mathrm{a}$ & $1.68 \mathrm{a}$ & $0.13 \mathrm{a}$ & $0.08 \mathrm{~b}$ & $0.09 \mathrm{a}$ & $0.065 \mathrm{a}$ \\
\hline
\end{tabular}

Table 2. Chemical composition of maize grains from cultivars QPM and Hybrid subjected to different treatments in 2014 and 2015.

\begin{tabular}{|c|c|c|c|c|c|c|c|c|c|c|c|c|}
\hline \multirow[t]{2}{*}{ Treatments } & \multicolumn{2}{|l|}{$\begin{array}{l}\text { Lipids } \\
\left(\mathrm{g} . \mathrm{kg}^{-1}\right)\end{array}$} & \multicolumn{2}{|l|}{$\begin{array}{l}\text { Minerals } \\
\left(\mathrm{g} \cdot \mathrm{kg}^{-1}\right)\end{array}$} & \multicolumn{2}{|c|}{$\begin{array}{l}\text { Carbohydrates } \\
\left({\left.\mathrm{g} . \mathrm{kg}^{-1}\right)}\right.\end{array}$} & \multicolumn{2}{|l|}{$\begin{array}{l}\text { Starch } \\
\left(\mathrm{g} .100 \mathrm{~g}^{-1}\right)\end{array}$} & \multicolumn{2}{|c|}{$\begin{array}{l}\text { Reducing sugars } \\
\left({\left.\mathrm{g} .100 \mathrm{~g}^{-1}\right)}^{-}\right.\end{array}$} & \multicolumn{2}{|c|}{$\begin{array}{l}\text { Crude fiber } \\
\left(\mathrm{g} .100 \mathrm{~g}^{-1}\right)\end{array}$} \\
\hline & QPM & Hybrid & QPM & Hybrid & QPM & Hybrid & QPM & Hybrid & QPM & Hybrid & QPM & Hybrid \\
\hline \multicolumn{13}{|l|}{2014} \\
\hline LC & $232.15 \mathrm{ab}$ & $285.52 \mathrm{a}$ & $7.07 b$ & $49 a$ & $500.79 \mathrm{bc}$ & $405.48 b$ & 21 bc & $42.53 \mathrm{a}$ & $4.88 \mathrm{ab}$ & $3.17 \mathrm{~b}$ & $4.03 a$ & $4.22 \mathrm{a}$ \\
\hline LA & $172.57 \mathrm{c}$ & $255.6 \mathrm{ab}$ & $13.92 \mathrm{~b}$ & $32.2 \mathrm{ab}$ & $576.93 \mathrm{a}$ & $466.1 \mathrm{a}$ & $50.61 \mathrm{a}$ & $17.89 \mathrm{c}$ & $5.79 a$ & $5.44 \mathrm{a}$ & $2.11 \mathrm{c}$ & $2.86 \mathrm{bc}$ \\
\hline LG & $221.32 \mathrm{ab}$ & $242.3 \mathrm{ab}$ & $34.75 a$ & $31.02 \mathrm{ab}$ & $483.28 c$ & $475.1 \mathrm{a}$ & $14.93 \mathrm{~d}$ & $18.67 \mathrm{c}$ & $5.16 \mathrm{ab}$ & $5.29 a$ & $2.77 b c$ & $2.05 \mathrm{c}$ \\
\hline GA & $230.1 \mathrm{ab}$ & $251.07 \mathrm{ab}$ & $15.17 b$ & $44.3 \mathrm{a}$ & $508.16 b c$ & $439.46 \mathrm{ab}$ & $21.5 \mathrm{~b}$ & $20.97 c$ & $6.13 \mathrm{a}$ & $2.67 \mathrm{~b}$ & $1.58 \mathrm{c}$ & $3.36 \mathrm{~b}$ \\
\hline $\mathrm{GC}$ & $253.42 \mathrm{a}$ & $235.45 b$ & $12.55 \mathrm{~b}$ & $32.52 \mathrm{ab}$ & $479.95 \mathrm{c}$ & $449.55 \mathrm{ab}$ & $15.04 \mathrm{~d}$ & $21.7 c$ & $6.03 a$ & $4.29 a$ & $2.11 \mathrm{c}$ & $4.51 \mathrm{a}$ \\
\hline c & $221.77 \mathrm{~b}$ & $240.62 \mathrm{ab}$ & $14.32 \mathrm{~b}$ & $14.87 \mathrm{~b}$ & $526.87 \mathrm{~b}$ & $498.46 \mathrm{a}$ & $15.59 \mathrm{~cd}$ & $28.55 b$ & $3.94 \mathrm{~b}$ & $5.02 \mathrm{a}$ & $3.31 \mathrm{ab}$ & $2.2 \mathrm{c}$ \\
\hline \multicolumn{13}{|l|}{2015} \\
\hline LC & $231.35 \mathrm{a}$ & 241.77 a & $25.92 \mathrm{c}$ & $54.65 \mathrm{~b}$ & $449.37 d$ & $465.36 b$ & $33.86 \mathrm{ab}$ & $29.24 \mathrm{a}$ & $7.37 a$ & $5.31 \mathrm{c}$ & $6.58 \mathrm{a}$ & $2.68 c$ \\
\hline LA & $207.62 \mathrm{ab}$ & 205.9 b & $51.47 b$ & $83.35 \mathrm{a}$ & $515.1 \mathrm{~b}$ & $473.74 \mathrm{~b}$ & $43.04 \mathrm{a}$ & $23.69 a$ & $7.27 a$ & $4.97 \mathrm{c}$ & $5.16 \mathrm{c}$ & $2.43 \mathrm{c}$ \\
\hline LG & $151.22 \mathrm{c}$ & $202.45 b$ & $49.17 \mathrm{~b}$ & $39.9 \mathrm{~b}$ & $554.1 \mathrm{a}$ & $492.44 \mathrm{~b}$ & $31.75 \mathrm{bc}$ & $26.72 a$ & $4.26 \mathrm{c}$ & $5.71 b c$ & $3.39 \mathrm{~b}$ & $5.74 \mathrm{a}$ \\
\hline GA & $180.97 \mathrm{bc}$ & $219.07 \mathrm{ab}$ & $65.52 \mathrm{a}$ & $50.67 \mathrm{~b}$ & $497.42 \mathrm{bc}$ & $480.87 \mathrm{~b}$ & $23.77 \mathrm{~d}$ & $22.89 a$ & $6.46 \mathrm{~b}$ & $7.89 a$ & $3.92 \mathrm{~b}$ & $4.17 \mathrm{~b}$ \\
\hline $\mathrm{GC}$ & $205.02 \mathrm{ab}$ & $220.02 \mathrm{ab}$ & $4807 \mathrm{~b}$ & $51.97 b$ & $484.07 b c$ & $469.1 \mathrm{~b}$ & $24.49 \mathrm{~cd}$ & $26.89 a$ & $3.05 \mathrm{~d}$ & $8.16 \mathrm{a}$ & $3.91 \mathrm{~b}$ & $4.45 a b$ \\
\hline C & 228.67 a & $224.77 a b$ & $57.25 \mathrm{ab}$ & $16.62 \mathrm{c}$ & $468.68 \mathrm{~cd}$ & $543.35 \mathrm{a}$ & $35.57 \mathrm{ab}$ & $32.50 \mathrm{a}$ & $4.45 c$ & $6.44 \mathrm{~b}$ & $2.26 \mathrm{c}$ & $3.9 \mathrm{bc}$ \\
\hline
\end{tabular}




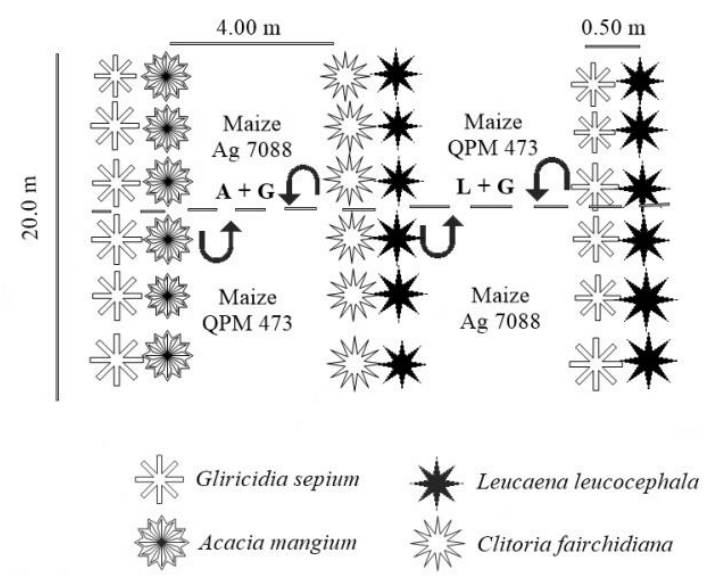

Fig 1. Scheme showing the distribution of double legume rows used for biomass deposition. Maize cultivars BR 473 and AG 7088 were simultaneously seeded in the central space between double legume rows.

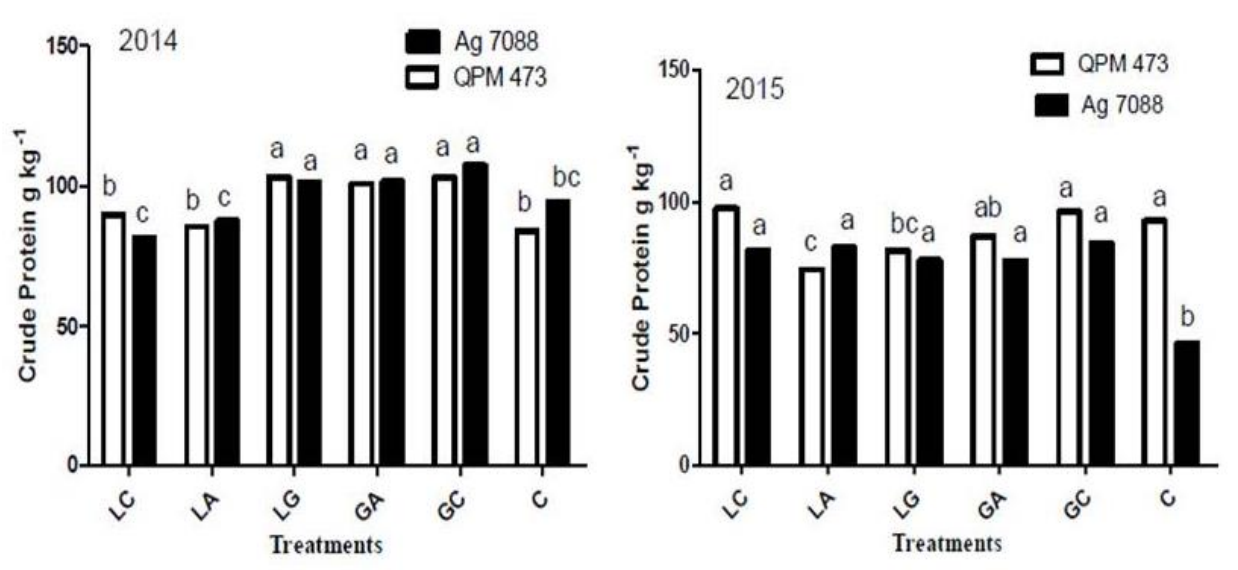

Fig 2. Protein content in maize cultivars QPM and Hybrid subjected to different treatments in 2014 and 2015. *LC = Leucaena and Clitoria; LA = Leucaena and Acacia; LG = Leucaena and Gliricidia; GA = Gliricidia and Acacia; GC = Gliricidia and Clitoria; C = control. In (a) QPM and (b) Hybrid. Different letters above the bars show differences between treatments applied to the two cultivars in the Duncan's test, at $p \leq 0.05$. 
Table 3. Analytical curve of the amino acid standards used for data comparison in order to analyze the samples from different treatments.

\begin{tabular}{lcc}
\hline Amino acids & Regression equation & $\mathrm{R}^{2}$ \\
\hline Aspartic Acid (Asp) & $y=1 E+08 x+884059$ & 0.9919 \\
Serine (Ser) & $y=2 E+08 x+29716$ & 0.9920 \\
Glutamine (Glu) & $y=1 E+08 x+116341$ & 0.9762 \\
Arginine (Arg) & $y=5 E+07 x+188120$ & 0.9862 \\
Threonine (Thr) & $y=2 E+08 x+209166$ & 0.9967 \\
Tyrosine (Tyr) & $y=4 E+07 x+195909$ & 0.9881 \\
Tryptophan (Trp) & $y=3 E+08 x+884059$ & 0.9898 \\
Methionine (Met) & $y=2 E+08 x+808670$ & 0.9934 \\
\hline
\end{tabular}

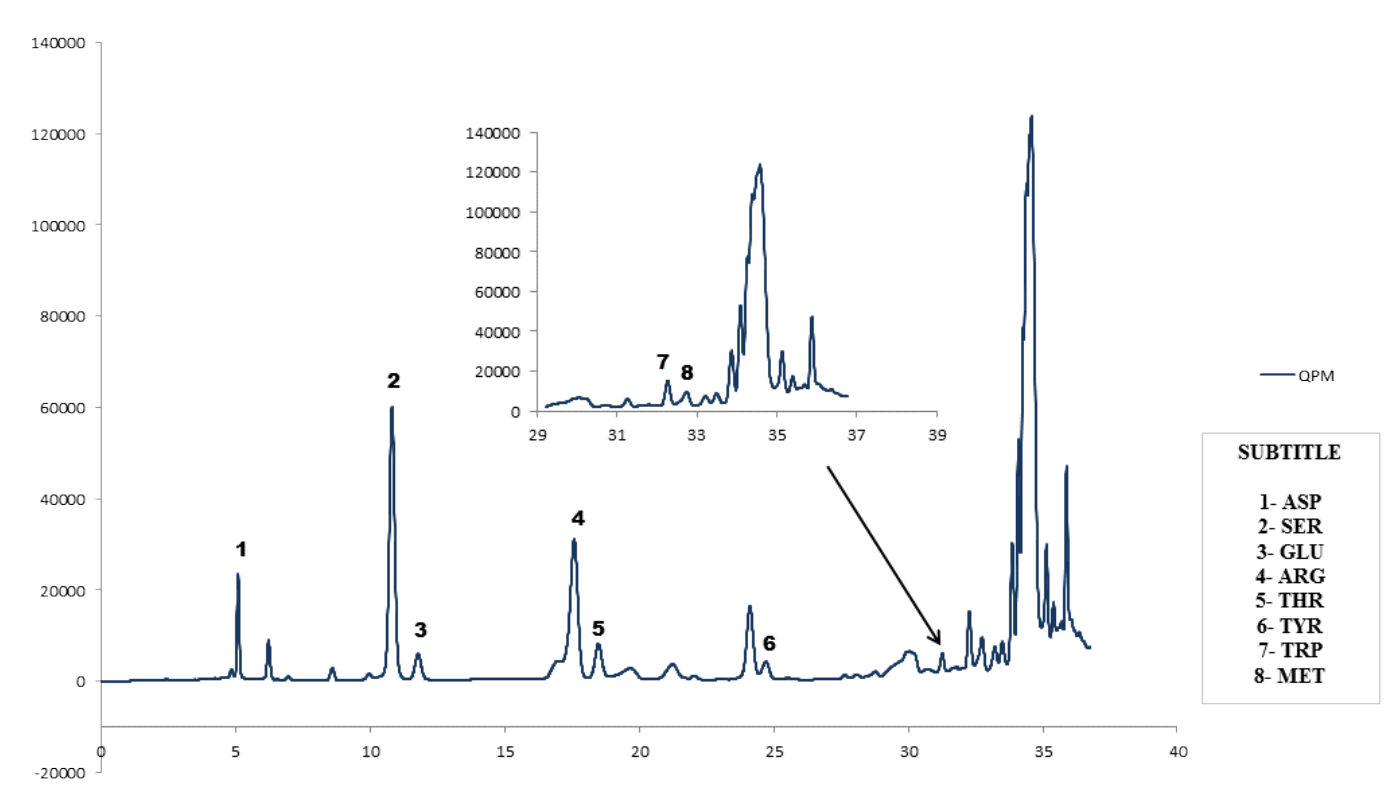

Fig 3. Chromatogram showing the amino acid profile of one of the herein analyzed maize grain QPM samples. * Aspartic Acid (Asp), serine (Ser), glutamine (Glu), arginine (Arg), threonine (Thr), tyrosine (Tyr), tryptophan (Trp), and methionine (Met). 


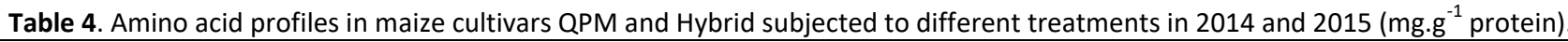

\begin{tabular}{|c|c|c|c|c|c|c|c|c|c|c|c|c|c|c|}
\hline \multirow{2}{*}{ Treatments } & \multirow{2}{*}{$\begin{array}{l}\text { Asp } \\
\text { QPM }\end{array}$} & \multirow[b]{2}{*}{ Hybrid } & \multicolumn{2}{|l|}{ Ser } & \multicolumn{2}{|l|}{ Glu } & \multicolumn{2}{|l|}{$\operatorname{Arg}$} & \multicolumn{2}{|l|}{ Thr } & \multicolumn{2}{|l|}{ Tyr } & \multicolumn{2}{|l|}{$\frac{T T p}{T-1}$} \\
\hline & & & QPM & Hybrid & QPM & Hybrid & QPM & Hybrid & QPM & Hybrid & QPM & Hybrid & QPM & Hybrid \\
\hline \multicolumn{15}{|l|}{2014} \\
\hline LC & $13.69 b$ & $12.17 \mathrm{c}$ & $16.3 \mathrm{a}$ & $8.1 \mathrm{~d}$ & $1.31 \mathrm{c}$ & $1.57 \mathrm{~cd}$ & $35.15 a$ & $24.83 b$ & $17.94 \mathrm{a}$ & $17.84 \mathrm{a}$ & $1.84 \mathrm{a}$ & -- & $0.8 \mathrm{a}$ & -- \\
\hline LA & $15.01 \mathrm{~b}$ & $14.32 \mathrm{~b}$ & $16.29 a$ & $15.3 \mathrm{~b}$ & $2.91 \mathrm{~b}$ & $2.17 \mathrm{c}$ & $40.64 \mathrm{a}$ & $30.0 \mathrm{a}$ & $18.95 \mathrm{a}$ & $15 a$ & $2.2 \mathrm{a}$ & -- & $1.49 \mathrm{a}$ & -- \\
\hline LG & $12.45 b$ & $11.23 \mathrm{c}$ & $9.1 \mathrm{~b}$ & $6.87 \mathrm{e}$ & $1.24 c$ & $2.03 \mathrm{c}$ & $26.13 \mathrm{ab}$ & $26.18 b$ & $17.19 \mathrm{a}$ & $17.11 \mathrm{a}$ & $0.73 \mathrm{~b}$ & -- & $1.27 a$ & -- \\
\hline $\mathrm{GA}$ & $19.26 \mathrm{a}$ & $17 a$ & $17.09 \mathrm{a}$ & $16.5 \mathrm{a}$ & $2.18 \mathrm{bc}$ & $10.19 \mathrm{a}$ & $41.56 \mathrm{a}$ & $15 \mathrm{c}$ & $18.15 \mathrm{a}$ & $14 a b$ & $1.05 \mathrm{~b}$ & -- & $1.13 \mathrm{a}$ & -- \\
\hline GC & $13.4 \mathrm{~b}$ & $16 \mathrm{a}$ & $10.45 \mathrm{~b}$ & $10 \mathrm{c}$ & $5.5 \mathrm{a}$ & $4.5 \mathrm{~b}$ & $17.85 \mathrm{~b}$ & $19.28 \mathrm{bc}$ & $18.1 \mathrm{a}$ & $11 \mathrm{~b}$ & $1.75 \mathrm{a}$ & -- & $0.7 a$ & -- \\
\hline c & $13.4 \mathrm{~b}$ & $11.87 \mathrm{c}$ & $10.31 \mathrm{~b}$ & $7.2 \mathrm{de}$ & $2.26 \mathrm{bc}$ & $1.03 \mathrm{~d}$ & $33.42 \mathrm{a}$ & $25 \mathrm{bc}$ & $18.03 \mathrm{a}$ & $15 \mathrm{a}$ & $0.4 \mathrm{~b}$ & -- & $0.45 \mathrm{a}$ & -- \\
\hline \multicolumn{15}{|l|}{2015} \\
\hline LC & $12.5 \mathrm{c}$ & $11.78 \mathrm{c}$ & $5.5 \mathrm{e}$ & $7.99 \mathrm{c}$ & $2.24 \mathrm{~d}$ & $1.01 \mathrm{c}$ & $27.41 \mathrm{~b}$ & $86.39 \mathrm{ab}$ & $17 c$ & $18.99 \mathrm{a}$ & $1.85 \mathrm{~d}$ & $1.55 c$ & $1.05 \mathrm{c}$ & $0.27 c$ \\
\hline LA & $15.5 \mathrm{~b}$ & $18.11 \mathrm{a}$ & $9 d$ & $27.24 \mathrm{~b}$ & $0.94 \mathrm{e}$ & $3.11 \mathrm{~b}$ & $21.16 \mathrm{~b}$ & $62.23 \mathrm{~b}$ & $17.3 \mathrm{c}$ & $18.68 \mathrm{a}$ & $2.55 \mathrm{~cd}$ & $3.44 \mathrm{ab}$ & $0.2 \mathrm{~d}$ & $1.15 \mathrm{~b}$ \\
\hline LG & $24.34 \mathrm{a}$ & $15.08 \mathrm{~b}$ & $49.33 \mathrm{a}$ & $17.46 \mathrm{bc}$ & $9.33 \mathrm{~b}$ & $2.34 \mathrm{bc}$ & $115.25 \mathrm{a}$ & $51.28 b$ & $21.18 b c$ & $18.89 \mathrm{a}$ & $9.32 \mathrm{a}$ & $2.04 \mathrm{bc}$ & $3.91 \mathrm{a}$ & $1.01 \mathrm{~b}$ \\
\hline GA & $11.41 \mathrm{c}$ & $18.45 \mathrm{a}$ & $9.12 \mathrm{~d}$ & $25.84 \mathrm{~b}$ & $2.55 \mathrm{~d}$ & $4.04 \mathrm{~b}$ & $27.08 \mathrm{~b}$ & $58.98 \mathrm{~b}$ & $18.02 \mathrm{c}$ & $20.15 a$ & $1.6 \mathrm{~d}$ & $4.79 \mathrm{ab}$ & $0.26 \mathrm{~d}$ & $1.92 \mathrm{a}$ \\
\hline $\mathrm{GC}$ & $24.89 a$ & $18.43 a$ & $25.29 b$ & $42.1 \mathrm{a}$ & $5.7 c$ & $8.64 \mathrm{a}$ & $129 \mathrm{a}$ & $104.77 \mathrm{a}$ & $25.1 \mathrm{~b}$ & $21.31 \mathrm{a}$ & $8.48 \mathrm{~b}$ & $5.4 \mathrm{a}$ & $3.17 \mathrm{~b}$ & $2.2 \mathrm{a}$ \\
\hline C & $25.03 \mathrm{a}$ & $14.23 \mathrm{~b}$ & $10.5 \mathrm{c}$ & $22.28 b$ & $14.49 \mathrm{a}$ & $2.81 \mathrm{~b}$ & $30.13 b$ & $51.43 \mathrm{~b}$ & $36.19 \mathrm{a}$ & $19.19 \mathrm{a}$ & $2.91 \mathrm{c}$ & $0.85 \mathrm{c}$ & $1.11 \mathrm{c}$ & $1.24 b$ \\
\hline
\end{tabular}

(a) Tyrosine; Trp = Tryptophan.Different letters above the bars show differences between treatments applied to the two cultivars in the Newman-Keuls test, at $P \leq 0.05$.

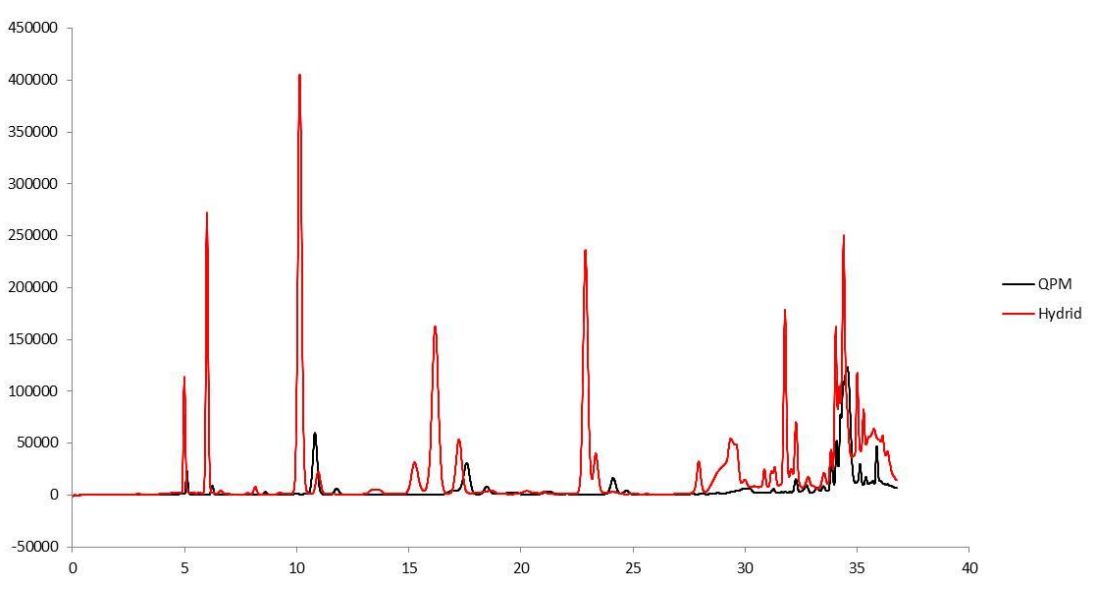

Fig 4. Chromatogram showing the amino acid profile for the maize cultivars QPM and Hybrid. 
these factors in the soil, as well as on crop-type and other factors such as water stress and fertilizer application (Rengel et al., 1999; Ikram et al., 2010). Legume-biomass application increased the content of most minerals found in maize grains, mainly phosphorus. The QPM cultivar showed very low lipid content in certain treatments in both cultivation periods. Miao et al. (2006) found low oil and starch contents in QPM cultivars treated with nitrogen fertilizers. According to Vasconcellos (1994), that genetic material is responsible for the greatest lipid content variation. Wegarya et al. (2011) stated that decreased lipid content leads to increased grain yield in some studies in maize. The low starch and fiber contents recorded in the present study were consistent due to the increased protein content in both cultivars. In addition, fiber content reduction is a desirable feature to improve the palatability and digestibility of maize grains to animals (Watson and Ramstad, 1987). According to Almodares et al. (2009), the protein content found in both cultivars meets the recommended levels, which may range

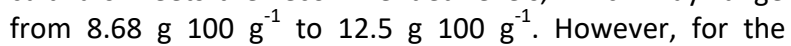
protein content accumulated in treated QPM grains in 2015 was not higher than the recorded for the control. According to Ngaboyisonga et al. (2012), soil nitrogen level affects protein and tryptophan concentrations in maize grains. Imolesi et al. (2001) found that nitrogen fertilization increased the protein concentration in the grain, reduced the zein content, and increased the lysine content. According to Masaero et al. (2001), nitrogen fertilization favors the link between the amount of protein stored in the grain and plant nutritional status. The increased protein content derives from increased amino acid formation, leading to improved grain quality (Almodares et al., 2009). According to Silva et al. (2016), the different protein contents generated by legume-biomass treatments evidenced that proper crop management leads to increased grain quantity and quality.

The results for amino acid content showed that the quantity and quality of chemical compounds in the grains were affected by legume-biomass addition. By analyzing the crude protein values and amino acid levels per treatment, it was found that treatments using high protein content showed high levels of most of the assessed amino acids; thus, the protein quality in maize grains depends on the profile of amino acids found in them(Blumenthal et al., 2008). However, high protein levels may not be associated with high amino acid levels, but, rather, with nitrogen accumulation (in its ammonium and nitrate forms) in the plant and grain (Schmidt et al., 2004). In addition, handling conditions and genetic materials also influence some amino acids; the QPM cultivar showed amino acid levels higher than those found in common maize (Prasanna et al., 2001).

Arginine content decreased due to increased crude protein content, corroborating the results by Huq (1983). The low threonine content recorded for the QPM cultivar in the 2015 crop, in comparison to the total protein content, was caused by content at the time the crop was subjected to higher nitrogen fertilization (Vasconcellos, 1994). The low serine contents found in the two cultivars, mainly in the 2015 crop, followed the downward trend resulting from the total protein increase (Radulov et al., 2012). Results suggested that tyrosine and glutamine contents increased due to legume-biomass application. According to Mason and Mason
(2012), nitrogen fertilization in maize cultivars tends to increase tyrosine and glutamine levels.

Treatments using Leucaena residues, mainly LC, had positive effects on the grain quality in the two cultivars. The positive effect of the Leucaena residue derived from greater nitrogen and potassium release associated with improvements in soil physical conditions (Moura et al., 2012). Recent studies indicated that high-quality residues or residues with added nutrients were very efficient in stabilizing organic carbon in the soil (Verchot et al., 2011). Bertalot et al. (2014) found that the alley cropping system stimulates increase in nutrient concentration in leaf tissues, and that Leucaena helps to increase crop yield. However, the presence of exotic species in the residue mix may be advantageous; it improved protein content in the hybrid cultivar subjected to the GC treatment. Nevertheless, the positive effects from these species can be neutralized during plant growth (Schmidt et al., 2004). Soil coating with legume-biomass is essential for soil temperature and humidity maintenance in Maranhão State, since the soil in the region presents cohesive characteristics resulting from fine sand prevalence (Moura et al., 2008).

\section{Materials and methods}

\section{Plant materials (Legumes and maize plants)}

The experiment was carried out between January and June 2014, and between January and June 2015 at Maranhão State University, São Luís, MA, Brazil (Latitude $2^{\circ} 30^{\prime} \mathrm{S}$; Longitude $\left.44^{\circ} 18^{\prime} \mathrm{W}\right)$. The climate in the region is characterized as tropical and semi-humid, with two welldefined seasons, namely: rainy (January-June) and dry season; there is water deficit between July and December. Mean annual rainfall was 1457.5 mm.year ${ }^{-1}$, and minimum and maximum temperatures during the experiment were $27^{\circ} \mathrm{C}$ and $37^{\circ} \mathrm{C}$, respectively. Water stress was calculated after 4 days without rain (Benjamin et al., 2003; Moura et al., 2009). According to Moura et al. (2012), the soil was characterized as cohesive and classified as sandy-dystrophic red-yellow Argisol. It was composed of $260 \mathrm{~g} \cdot \mathrm{kg}^{-1}$ of coarse sand, $560 \mathrm{~g} . \mathrm{kg}^{-1}$ of fine sand, $80 \mathrm{~g} . \mathrm{kg}^{-1}$ of silt, and $100 \mathrm{~g} . \mathrm{kg}^{-1}$ of clay.

The experimental design followed randomized blocks, with a $6 \times 2$ factorial arrangement and four repetitions. The legume residues tested herein belonged to four perennial species: two high-quality residue plants (Gliricidia sepium Jacq. and Leucaena leucocephala Lam.) and two low-quality residue plants (Clitoria fairchildiana Howard and Acacia mangium Willd) (Aguiar et al., 2010). Legumes were sown in double rows distributed in $20 \mathrm{~m} \times 4 \mathrm{~m}$ plots.

Treatments used in the current study were Gliricidia sepium Jacq. + Clitoria fairchildiana Howard (GC); Gliricidia sepium Jacq. + Acacia mangium Willd (GA); Leucaena leucocephala Lam. + Gliricidia sepium Jacq. (LG); Leucaena leucocephala Lam. + Clitoria fairchildiana Howard (LC); Leucaena leucocephala Lam. + Acacia mangium Willd (LA), and the Control (without legumes; C). The subplots were composed of two maize cultivars, QPM BR 473 and the hybrid AG 7088, which were cultivated in four rows spaced $0.90 \mathrm{~m} \times 0.30 \mathrm{~m}$ from each other at a density of 5 plants. $\mathrm{m}^{-2}$ (Fig. 1). 
The fertilization system applied to the maize crop consisted of $120 \mathrm{~kg} \cdot \mathrm{ha}^{-1}$ of $\mathrm{P}_{2} \mathrm{O}_{5}$ in the form of triple superphosphate, 5 $\mathrm{kg} \cdot \mathrm{ha}^{-1}$ of $\mathrm{Zn}$ in the form of zinc sulfate, $120 \mathrm{~kg} \cdot \mathrm{ha}^{-1}$ of $\mathrm{K}_{2} \mathrm{O}$ in the form of potassium chloride, and $100 \mathrm{~kg} \cdot \mathrm{ha}^{-1}$ of $\mathrm{N}$ in the form of urea. Two applications were conducted; one at sowing time and the other at the V6 stage of maize growth. Legume-biomass was provided in the following amounts after maize sowing: $4.13 \mathrm{mg} \cdot \mathrm{ha}^{-1} \mathrm{GA}$ and GC; $3.63 \mathrm{mg} \cdot \mathrm{ha}^{-1}$ $L A, L G$, and $L C$.

\section{Sample preparation}

Five cobs were harvested per treatment, after the maize grains reached the phenological maturity period. Next, the ears were threshed, and the grains were packed and frozen at $-20^{\circ} \mathrm{C}$. The grains were lyophilized (Liotop L101 lyophilizer), ground (Induction engine 1CV-220V/Tecnal), sieved through a mesh (n. 30), and vacuum bagged (Foodsaver/Oster Sealer).

\section{Physicochemical analyses}

Parameters such as lipids, mineral residue, fibers, and proteins (expressed in g. $\mathrm{kg}^{-1}$ ) were set described by the methodology by AOAC (2005). The carbohydrate content $\left(\mathrm{g} . \mathrm{kg}^{-1}\right)$ was estimated by subtracting the sum of moisture, lipids, protein, fibers, and mineral residue from 1000 (Brasil, 2003). The total of reducing sugars was quantified according to the dinitrosalicylic acid method (DNS) (Miller, 1959) in UVVIS spectrophotometer (SP22-Biospectro). The starch content was set according to the Lane-Eynon method (Carvalho et al., 2002). The main minerals were set according to the AOAC (2005) and quantified in inductivelycoupled plasma optical emission spectrometer (Varian 720ES).

\section{Amino acids}

Amino acids were quantified through the adaptation of chromatographic methods described by Dai et al. (2014) and Jones and Gilligan (1983). The samples were diluted after subjection to acid hydrolysis in order to set amino acids concentration at $1000 \mathrm{ppm}$. Samples were derivatized in 0.1 $M$ sodium acetate and ortho-phthalaldehyde (OPA) before injection. The analyses were carried out in high-performance liquid chromatographer (HPLC model DGU-20A, Shimadzu) coupled to a fluorescence detector (model RF-10AXL, Shimadzu) by using the LC Solution software. The wavelengths used were $340 \mathrm{~nm}$ (excitation) and $455 \mathrm{~nm}$ (emission). Luna $\mathrm{C}_{18}(250 \times 4.6 \mathrm{~mm}$ and $5 \mu \mathrm{m})$ Phenomenex column was employed. Gradients were formed by two solvents. The mobile phase consisted of $0.1 \mathrm{M}$ methanol and sodium acetate buffer, $\mathrm{pH} 7.0$, flow $1.9 \mathrm{~mL} \cdot \mathrm{min}^{-1}$, sample volume $20 \mu \mathrm{L}$, and run time $45 \mathrm{~min}$. The rate of solvent A (\%) was set as follows: $0 \mathrm{~min}, 0 \%$; $2 \mathrm{~min}, 25 \%$; $13 \mathrm{~min}, 25 \% ; 18$. min, 37\%; $28 \mathrm{~min}, 60 \%$; 34-45 min, 100\%. Sigma reactants and solvents showing purity content higher than $90 \%$ and HPLC standard were used in the current study. The standard amino acid solution was prepared at concentration $10 \mu \mathrm{M}$.

\section{Statistical analyses}

Results were subjected to analysis of variance (ANOVA); means were compared through Duncan's test at significance level $* p<0.05$, in the InfoStat software (InfoStat Group, Agrarian Sciences School, National University of Córdoba, Argentina).

\section{Conclusion}

Results of the present study evidenced that different legume-biomass combinations affected the chemical composition of grains in both assessed maize cultivars. These results suggest that the nitrogen accumulation capacity of each genotype depends on plant nitrogen use and accumulation efficiency. Legume-biomass application increased the content of most minerals. Fiber and starch presented low values, which were compensated by the increased protein content resulting from legume-based treatments. However, the quality of maize grains improved due to increased tyrosine and glutamine content, as well as to decrease amounts of other amino acids, aiding crude protein content increase under the legume-based treatments.

\section{Acknowledgements}

To the Postgraduate Program of the Biodiversity and Biotechnology Network of the Legal Amazon. To the Federal Institute of Education, Science and Technology of Maranhão for the financial support.

\section{References}

Almodares A, Jafarina M, Hadi MR (2009) The effects of nitrogen fertilizer on chemical compositions in corn and sweet sorghum. J Agric Environ Sci, 6(4): 441-446.

Aguiar ACF, Bicudo SJ, Costa Sobrinho JRS, Martins ALS, Coelho KPO, Moura EG (2010) Nutrient recycling and physical indicators of an alley cropping system in a sandy loam soil in the Pre-Amazon Region of Brazil. Nutri Cycl Agroecosys, 86: 189-198.

Association of Oficial Analytical Chemists (AOAC) (2005) Official methods of analysis (16th edn). AOAC International, Washington, DC.

Benjamin JG, Nielsen DC, Vigi LMF (2003) Quantifying effects of soil conditions on plant growth and crop production. Geoderma 116: 137-148.

Bertalot MJA, Guerrini IA, Mendoza E, Pinto MSV (2014) Productivity, leaf nutrient content and soil carbon stocked in agroforestry and traditional management of maize (Zea mays L.). American J Plant Sci 5: 884-898.

Blumenthal J, Baltens D, Cassan KG, Mason S, Pavlista A (2008) Importance and effect of nitrogen on crop quality and health, In: Nitrogen in the environment: sources, problems, and management, 2rd edn. Chapter3. 21.

Brasil. Anvisa. RDC no 360, de 23 dezembro de 2003.

Brito $A B$, Stringhini JH, Cruz CPda, Xavier SAG, Silva LAF da, Café MB, Leandro NSM (2005) Avaliação nutricional do gérmen integral de milho para aves. Cien Animal Bras. 6: 19-26. 
Carvalho HH, Jong EV, Belló RM, Souza RB de, Terra MF (2002) Alimentos: métodos físicos e químicos de analises, UFRGS, Porto Alegre, 180.

Canas RA, Amior N, Quillere I, Hirel B (2011) An integrated statistical analysis of the genetic variability of nitrogen metabolism in the ear of three maize inbred lines (Zea mays L.). J Exp Bot 62(7): 2309-2318.

Cattanio JH, Kuehne R, Vlek PLG (2008) Organic material decomposition and nutrient dynamics in a mulch system enriched with leguminous trees in the Amazon. Rev Bras Ciênc Solo. 32: 1073-1086.

CIMMYT (2004) Maize inbred lines release by CIMMYT: a compilation of maize lines (CMLs), CIMMYT, Mexico, 59.

Dai Z, Wu Z, Jia S, Wu S (2014) Analysis of amino acid composition in proteins of animal tissues and foods as precolumn o-phthaldialdehyde derivatives by HPLC with fluorescence detection. J Chromatogr. B 964(1): 116-127.

Franco AA, Balieiro F de C (2000) The Role of biological nitrogen fixation in land reclamation, agroecology and sustainability of tropical agriculture, In: Rochamiranda CE (ed)Transition to global sustainability: the contribution of brazilian Science, ed. Rio de Janeiro, Academia Brasileira de Ciências, 209-234.

Garnett T, Conn V, Kaiser BN (2009) Root based approaches to improving nitrogen use efficiency in plants. Plant Cell Environ 32(9): 1272-1283.

Glória S, Almeida V, Costa V, Henriques Jr E, Martins L, Paula H, Silva ME, Santos C, Malaquias CC (2004) Avaliação protéica de uma nova multimistura com base no milho QPM BR 473. Rev Nutri 17(3):379-385.

Huq ISM (1983) Fertizer effects on yield, nitrogen contente and amino acid composition of maize grain. Agronomie 3(10): 965-970.

Imolesi A, Pinho EV de R V, Pinho RGV, Pinho RGV, Vieira M das GC, Corrêa RSB (2001) Efeito da adubação nitrogenada em características morfo-agronômicas e nos padrões eletroforéticos de proteínas e isoenzimas de sementes de milho. Rev Bras Sementes 23: 17-25.

Ikram U, Mohammed A, Arifa F (2010) Chemical and nutritional properties of some maize (Zea mays L.) varieties grown in NWFP. Pakistan J Nutrit 9:1113-1117.

Jones B, Gilligan JP (1983) O-phthaldialdehyde precolumn derivatization and reversed- phase high-performance liquid chromatography of polypeptide hydrolysates and physiological fluids. J Chromatogr B 266: 471-482.

Luscher A, Mueller-harvery I, Soussana JF, Rees RM, Peyraud JL (2016) Potencial of legume-based grassland-livestock systems in Europe: a review. Grass Forage Sci 69(2): 206228.

Mason SC, Mason EDC (2002) Agronomic practis influence maize grain quality, In: Basra AS, Randhawa LS (ed), Quality improvement in field crops, 73-80.

Masaero F, Gallo A, Zanfi C, Guiberti G, Spanghero M (2011) Effect of nitrogen fertilization on chemical composition and rumen fermentation of different parts of plants of three corn hybrids. Anim Feed Sci Technol 164(3): 207216.

Moura EG de, Silva AJ de F, Furtado MB, Aguiar A das F (2008) A Avaliação de um sistema de cultivo em aléias em um argissolo franco-arenoso da Região Amazônica. Rev Bras Ciênc Solo 32: 1735-1742.

Moura EG, Moura NG, Marques ES, Pinheiro KM, Costa Sobrinho JRS, Aguiar ACF (2009) Evaluating chemical and physical quality indicators for a structurally fragile tropical soil. Soil Use Manage 25(4): 368-375.

Moura EG, Oliveira AKC, Coutinho G, Pinheiro KM, Aguiar ACF (2012) Management of a cohesive tropical soil to enhance rootability and increase the efficiency of nitrogen and potassium use. Soil Use Manage 28(3): 370-377.

Mercadante AZ, Amaya DBR, Britton G (1997) HPLC and mass spectrophotometric analysis of carotenoids from mango. J Agric Food Chem 45(1): 120-123.

Miao YX, Mulla DJ, Robert PC, Hernandez JA (2006) Withinfield variation in corn yield and grain quality responses to nitrogen fertilization and hybrid selection. Agron J. 98(1): 129-140.

Miller GL (1959) Use of dinitrosalicylic acid reagent for determination of reducing sugar. Analytical Chemistry 31,426.

Naves MMV, Castro MVL de, Mendonça AL de, Santos GG, Silva MS (2011) Corn germ with pericarp in relation to whole corn: nutrient contents, food and protein efficiency and protein digestibility-corrected amino acid score. Cienc Tecnol Alime 31: 264-269.

Ngaboyisonga C, Njoroge K, Kirubi D, Githiri SM (2012) Quality protein maize under low $\mathrm{N}$ and drought environments: endosperm modification, protein and tryptophan concentrations in grains. Agric J 7(5): 327-338.

Prasanna BM, Vasal SK, Kassahun B, Singh NN (2001) Quality protein maize. Curr Sci 81: $1308-1319$.

Pretty J (2008) Agricultural sustainability: concepts, principles and evidence. Philos Trans R Soc Lond B Biol Sci 363(1491): 447-465.

Radulov I, Alexa E, Negrea M, Crista F, Berbecea A (2012) Nitrogen fertilization and mycotoxin accumulation influence upon protein and amino acid content of corn grains, http:// agris.fao.org/agris-search/search.do RS2013060236.

Rengel Z, Batten GD, Crowlwy DE (1999) Agronomic approaches for improving the micronutrient density in edible portions of field crops. Field Crop Res 60(1): 27-40.

Silva AGM, Aguiar ACF, Moura EG, Jorge N (2016) Influence of soil cover and $\mathrm{N}$ and $\mathrm{K}$ fertilization on the quality of biofortified QPM in the humid tropics. J Sci Food Agric 96(11): 3807-3812.

Schmidt A, Lima GJMM, Klein CH (2004) Composição química de híbridos de milho produzidos na safrinha em Marechal Cândido Rondon. Paraná, Embrapa/CNPSA, 4.

Vasconcellos CA (1994) Importância da adubação na qualidade do milho e do sorgo, In: SÁ, ME de BS (ed) Importância da adubação na qualidade dos produtos agrícolas, São Paulo,319-331.

Vasal SK (2001) High quality protein corn in Specialty corns. In: Hallauer AR (ed) Ames, 85-130.

Verchot LV, Dutaur L, Shepherd KD, Albrecht A (2011) Organic matter stabilization in soil aggregates: Understanding the biogeochemical mechanisms that determine the fate of carbon inputs in soils. Geoderma 161(3): 182-193.

Vivek BS, Krivanek AF, Palacios-rojas N, Twumasi-afriyie $S$, Diallo AO (2008) Breeding Quality Protein Maize (QPM): Protocols for Developing QPM Cultivars. CIMMYT, Mexico, 50

Vyn TJ, Tollenaar M (1998) Changes in chemical and physical quality parameters of maize grain during three decades of yield improvement. Field Crop Res 59(2): 135 -140. 
Zhao Y, Xi M, Zhang X, Lin Z, Ding C, Tang S, Liu Z (2015) Nitrogen effect on amino acid composition in leaf and grain of japonica rice during grain filling stage. J Cereal Sci 64: 29-33.

Watson AS, Ramstad PE (1987) Corn: Chemistry and Technology. AACC, St. Paul, MN, 605.

Watson AS, Ramsted PE (1999) Corn: chemistry and technology. Saint Paul, American Association of Cereal Chemists, 605.

Wegarya D, Maryke T, Labuschagne B, Bindiganavile S, Vivek BS (2011) Protein quality and endosperm modification of quality protein maize (Zea mays L.) under two contrasting soil nitrogen environments. Field Crop Res 121(3): 408-41.
Worku M, Banziger M, Friesen D, Erley GS auf'm, Host WJ, Vivek BS (2008) Relative importance of general combining ability and specific combining ability among tropical maize (Zea mays L.) inbreds under contrasting nitrogen environments. Maydica 53: 279-288.

Young VR, Pellett PL (1994) Plant proteins in relation to human protein and amino acid nutrition. Am J Clin Nutr 59(5): 1203S-1212S. 